\title{
Cold Tolerance at Germination and Seedling Stages of Rice: Methods of Evaluation and Characterization of Thirty Rice Genotypes under Stress Conditions
}

\author{
Javeed A. Lone ${ }^{1 *}$, M. Nisar Khan ${ }^{2}$, M. Ashraf Bhat ${ }^{1}$, Asif B. Shikari ${ }^{3}$, Shabir H. Wani ${ }^{4}$, \\ Najeeb R. Sofi ${ }^{4}$, M. Imran Khan ${ }^{5}$ and Rayees A. Lone ${ }^{1}$ \\ ${ }^{1}$ Division of Genetics and Plant Breeding, FoA, Sher-e- Kashmir University of Agricultural \\ Science and Technology of Kashmir, Wadura Sopore-193201, Jammu and Kashmir, India \\ ${ }^{2}$ Dryland Agriculture Research Station, Budgam, India \\ ${ }^{3}$ Division of Plant Biotechnology, Sher-e-Kashmir University of Agricultural Science and \\ Technology, Shalimar-190025, India \\ ${ }^{4}$ Sher-e-Kashmir University of Agricultural Science and Technology Shalimar, Rice Research \\ Station (MRCFC) Khudwani, India \\ ${ }^{5}$ Division of Agri-Statistics, Sher-e-Kashmir University of Agricultural Science and \\ Technology, Shalimar-190025, India \\ *Corresponding author
}

\begin{abstract}
Keywords
Abiotic stress, Controlled situation, Coleoptile growth, Radical regrowth, Low temperature

Article Info

Accepted:

10 December 2017

Available Online:

10 January 2018 where the indica subspecies is cultivated. Low temperatures can have direct impacts on rice plants during germination, vegetative growth, and reproductive stages. This study aims to identify a suitable technique to estimate rice (Oriza sativa L.) cold tolerance at the germination stage and identify the variability among 30 rice genotypes. Cold tolerance was evaluated by two methods: in method I, rice seeds were kept and germinated under two conditions; 28 days in $13^{\circ} \mathrm{C}$ and seven days in $28^{\circ} \mathrm{C}$; in experiment II, seedlings were kept at 72 hours 96 hours at $13^{\circ} \mathrm{C}$ and again 72 hours at $28^{\circ} \mathrm{C}$. In experiment I percentages of reduction in radicle and coleoptile length and germination percent and percent decline in germination were measured. In experiment II coleoptiles growth radical regrowth after the cold period were measured. Results showed that low temperature effects in both experiments were varied among studied genotypes. Highest germination was achieved in SKAU-402 fallowed by SI-6, K-332, SI-5 and SI-3 with less percent decline in germination that is, $0.13,0.17,0.24$ and 0.32 at $13^{\circ} \mathrm{C}$. Percentage of coleoptiles growth by low temperature $\left(13^{\circ} \mathrm{C}\right)$ was varied from 13.8 to $86.6 \%$. In experiment II, radicle regrowth values varied from 2.0 to $12.0 \mathrm{~mm}$, and SI-6,-SI-5, Kamad, SKAU-402 and K332, were the genotypes with high radicle regrowth.
\end{abstract}

A B S T R A C T

Rice is one of the most important staple foods among the cereal crops for half of the human population. Unlike other cereals such as wheat and barley, rice plants are susceptible to cold stress, which causes decrease in productivity, especially in regions 


\section{Introduction}

Rice (Oryza sativa L.) is the most important staple food crop for more than $60 \%$ of the global population and forms the cheapest source of food and energy. Rice occupied 39.16 million hectares with production and productivity of 85.59 million tonnes and 2185 $\mathrm{kg} \mathrm{ha}{ }^{-1}$ respectively, in India during 20122103. The production of rice was low during spring (48 lakh tonnes), compared to rainy season (84.1 lakh tonnes) during 2012-13 (INDIASTAT, 2013), The productivity of rice is particularly low in during spring due to cold, which is an important abiotic constraint, where low temperature prevails below $18{ }^{\circ} \mathrm{C}$. Datta and Datta (2006) reported that low temperature stress is one of the major abiotic factors which reduce rice yield in several countries. Losses can range from 0.5 to 2.5 ha1 (Singh et al., 2005) and grain yields can drop by up to $26 \%$ (Lee et al., 2001) mostly due to low temperature during the reproductive stage, even though cold temperature can be harmful during the entire developmental stage of rice plants, from germination to grain filling (Ye et al., 2009 and Cruz et al., 2013). As per Cruz and Milach (2013) good cold tolerance at the seedling stage is an important character for stable rice production, especially in direct seeding fields. Cold tolerance at germination and seedling emergence and early stages is essential to obtain optimum plant population. Breeding varieties for cold tolerance could be the better solution for the problem. However selection for tolerance requires a suitable and cost effective screening technology. Breeding cold tolerant varieties in rice is essential to reduce yield loss, for which information on various traits that contribute to tolerance is necessary (Priyanka, 2015). Keeping in view of the above problem the present study is taken up to evaluate cold tolerance in rice genotypes with a suitable method to estimate cold stress in thirty rice genotypes at the germination and seedling stages under controlled and stressed conditions, as well as introduce genotypes with high tolerance to cold stress in germination stage and also choose the best characters of resistance for use in breeding programs.

\section{Materials and Methods}

Thirty rice genotypes including pre released, released and germplasm genotype were studied in this research (Table 1). Seeds of all the thirty rice genotypes were collected from MRCFC Kudwani, Sher-e-Kashmir University of Agricultural Sciences and Technology of Kashmir. The cold tolerance evaluation was carried out in, Division of Biotechnology Sher-e-Kashmir University of Agricultural Sciences and Technology of Kashmir Shalimar,

To evaluate genotypes for cold tolerance, two methods were used (Cruz and Milach, 2004). In method I, seeds of 30 rice genotypes were germinated in two conditions that is, 28 days in $13^{\circ} \mathrm{C}$ (cold stress) and seven days in $28^{\circ} \mathrm{C}$ (control). Seeds were sterilized and followed by washing with distilled water to protect them against any fungal attack. They were placed between the two layers of filter paper in petri plates wetted with distilled water to keep them moist. The experiment was carried out in a completely randomized design with three replications of 10 seeds. Coleoptiles growth of the germinated seeds at $13^{\circ} \mathrm{C}$ were measured weekly for four weeks. For $28^{\circ} \mathrm{C}$ one measurement was taken at the end of the experiment. To evaluate cold tolerance the following formula was used: Germination percent $(\mathrm{GP} \%):=($ No. of normal seedlings / total No. of seeds planted $x$ 100). Only the seeds that had coleoptile and radicle were considered for calculation. Radicle and coleoptile length were obtained based on all the germinated seeds at the end of the experiment. 
In method II, seeds of thirty rice genotypes were sown under the following conditions: $28^{\circ} \mathrm{C}$ for 72 hours, $13^{\circ} \mathrm{C}$ for 96 hours and again 72 hours at $28^{\circ} \mathrm{C}$. The aim of this change in temperature was to provide field conditions because in field conditions there is a temperature variation. Length of radicle was measured two times: first, at the end of 96 hours at $13^{\circ} \mathrm{C}$ (LENGTH 1) and second at the end of second period of 72 hours at $28^{\circ} \mathrm{C}$ (LENGTH 2), according to the formula: RADREG $=($ LENGTH 2$)-($ LENGTH 1$)$.

In this experiment, evaluation of cold tolerance was carried out through coleoptiles growth and radicle regrowth, which was shown in the distinction between the second and the first measurements.

\section{Results and Discussion}

There were variations among the rice genotypes for traits related to germination percent, reduction in radicle and coleoptiles length and regrowth. Germination percentage showed significant differences among the genotypes. The germination percentage and percent decline in germination at $\left(13^{\circ} \mathrm{c}\right)$ was high in SKAU-402 (83.7\%) followed by K332 (80\%), SI-5 (43.3\%) and SI-3 (56.7\%).

The germination percentage and percent decline in germination at $\left(17^{\circ} \mathrm{c}\right)$ was highest in K332 (86.7\%) followed by SKAU-402 (88.3\%), SI-6 (80.0\%) and SI-3, SR-3, Jehlum with same ratio (76.7\%). Yoshida (1981) reported the greatest influence of temperature on germination. Blum (1988) suggested high germination percentage is important for early season cold tolerance in rice. Temperature below $18^{\circ} \mathrm{C}$ causes decreases in both the speed and percentage of rice seed germination $(\mathrm{Xu}$, 2008). Cruz et al., (2013) reported that low temperature stress may affect rice seed germination, avoiding development to the seedling stage. In direct seedling cultivation under the low temperature, germination and early growth of seedlings take place rapidly, (Suh et al., 2010). Germination percentage of rice genotypes under normal and cold temperature are compared (Table 2).

The germination percentage at $\left(13^{0} \mathrm{c}\right)$ was decreased to below $50 \%$ in the genotypes, IR52, China-1007, SKAU-411 and IR -73 while as the lowest germination at $\left(17^{0} \mathrm{c}\right)$ was obtained again in IR-52 (33.3\%) and China 1007 (36.7\%) which indicated cold susceptibility at germination rate. Sharifi (2010) evaluate 68 rice germplasms for cold tolerance at germination stage and showed that germination rate, radicle and coleoptile length were reduced under cold. The low germination under cold may be due to less metabolic activity and inactive enzymes that play key role in germination. Results also showed that lowest mean reduction upon both the temperatures $\left(13^{\circ} \mathrm{C}\right.$ and $\left.17^{\circ} \mathrm{C}\right)$ was observed in SKAU-402, SI-6 and K332 genotypes.

In relation to the reduction in coleoptiles, there was a significant difference at temperatures of $13^{\circ} \mathrm{C}$ and $17^{\circ} \mathrm{C}$ between genotypes (Table 3 ). Range of reduction in coleoptiles length for genotypes at $13^{\circ} \mathrm{C}$ was varied between 13.8 to 86.6 percent. SKAU 402, K-332, SI-5 and SI6 had the highest and SI-1, IR-52 and China1007 had the lowest amount of reduction in coleoptiles length due to cold stress $\left(13^{\circ}\right)$. Similarly range in genotypes at $17^{\circ} \mathrm{c}$ varies from 27.6 to 94.1 percent, SI-5 followed by SI-3, SKAU 402 and K-332. While as lowest values was obtained in SI-1, IR-52 and China 988. Among some studied characteristics in this study, reduction in coleoptiles length was one of the best characteristic for better distinction between the genotypes sensitively to cold stress (Miedema, 1982). Via comparison of coleoptile growth under normal temperature in relation to cold temperature we are able to show the genotypes response to cold stress effectively (Miedema, 1982). 
Table.1 List of rice genotypes used for evaluation of cold tolerance

\begin{tabular}{|c|c|c|c|c|c|}
\hline S. No & Genotypes & S. No & Genotypes & S. No & Genotypes \\
\hline 1 & $\mathrm{~K}-332 *$ & 11 & Kohsaar* & 21 & Kamad* \\
\hline 2 & SKAU-407** & 12 & Shalimar Rice-1* & 22 & China-1007* \\
\hline 3 & IR-24*** & 13 & SI-4*** & 23 & Shalimar Rice-3* \\
\hline 4 & IR-64*** & 14 & IR-52*** & 24 & SI-3*** \\
\hline 5 & IR-72*** & 15 & SI-17*** & 25 & HEERA* \\
\hline 6 & SI-1*** & 16 & China-988* & 26 & KOSHIHIKARI* \\
\hline 7 & Mushkbudji $* * *$ & 17 & SKAU-411** & 27 & SI-6*** \\
\hline 8 & SKAU-5 (K-39)* & 18 & Jehlum* & 28 & SI-7*** \\
\hline 9 & Shalimar Rice-2* & 19 & SKAU-408** & 29 & IR-70*** \\
\hline 10 & SKAU-402** & 20 & SI-5*** & 30 & SKAU-403*** \\
\hline
\end{tabular}

$*=$ Released, $* *=$ Pre released, $* * *=$ Germplasm

Table.2 Thirty rice genotype for seed and seedling parameters and their decline in germination percent and mean reduction under normal and stress conditions

\begin{tabular}{|c|c|c|c|c|c|c|}
\hline Genotypes & $\begin{array}{l}\text { Germination } \\
\text { 28deg }\end{array}$ & $\begin{array}{l}\text { Germination } \\
\text { 13deg }\end{array}$ & $\begin{array}{l}\text { Germinatio } \\
\mathrm{n}_{17 \mathrm{deg}}\end{array}$ & $\begin{array}{l}\text { Per cent decline } \\
\text { in Germination } \\
\text { 13deg }\end{array}$ & $\begin{array}{l}\text { Per cent decline } \\
\text { in Germination } \\
\text { 17deg }\end{array}$ & $\begin{array}{l}\text { Mean } \\
\text { reduction }\end{array}$ \\
\hline K332 & 96.7 & 80.0 & 86.7 & 0.17 & 0.10 & 0.14 \\
\hline SKAU-407 & 93.3 & 53.3 & 70.0 & 0.43 & 0.24 & 0.33 \\
\hline IR-24 & 83.3 & 56.7 & 73.3 & 0.32 & 0.12 & 0.22 \\
\hline IR-64 & 66.7 & 36.7 & 56.7 & 0.44 & 0.15 & 0.29 \\
\hline IR-72 & 73.3 & 33.3 & 53.3 & 0.55 & 0.27 & 0.41 \\
\hline SI-1 & 96.7 & 63.3 & 76.7 & 0.34 & 0.20 & 0.27 \\
\hline Mushkbudji & 90.0 & 46.7 & 76.7 & 0.48 & 0.15 & 0.31 \\
\hline SKAU-5 (K-39) & 96.7 & 53.7 & 70.0 & 0.44 & 0.28 & 0.36 \\
\hline Shalimar Rice-2 & 63.3 & 33.3 & 43.3 & 0.47 & 0.32 & 0.39 \\
\hline SKAU-402 & 96.7 & 83.7 & 88.3 & 0.13 & 0.09 & 0.11 \\
\hline Kohsaar & 93.3 & 60.0 & 76.7 & 0.36 & 0.18 & 0.27 \\
\hline Shalimar Rice-1 & 90.0 & 40.0 & 56.7 & 0.56 & 0.37 & 0.46 \\
\hline SI-4 & 93.3 & 40.0 & 40.0 & 0.57 & 0.57 & 0.57 \\
\hline IR-52 & 86.7 & 13.3 & 33.3 & 0.85 & 0.62 & 0.73 \\
\hline SI-17 & 90.0 & 40.0 & 56.7 & 0.56 & 0.37 & 0.46 \\
\hline China-988 & 86.7 & 43.3 & 70.0 & 0.50 & 0.19 & 0.34 \\
\hline SKAU-411 & 83.3 & 26.7 & 40.0 & 0.68 & 0.52 & 0.60 \\
\hline Jehlum* & 96.7 & 60.0 & 76.7 & 0.38 & 0.21 & 0.29 \\
\hline SKAU-408 & 86.7 & 50.0 & 56.7 & 0.42 & 0.35 & 0.38 \\
\hline SI-5 & 56.7 & 43.3 & 53.3 & 0.24 & 0.06 & 0.15 \\
\hline Kamad & 90.0 & 66.7 & 76.7 & 0.26 & 0.15 & 0.20 \\
\hline China-1007 & 43.0 & 13.3 & 36.7 & 0.69 & 0.15 & 0.42 \\
\hline Shalimar Rice-3 & 93.3 & 66.7 & 76.7 & 0.29 & 0.18 & 0.23 \\
\hline SI-3 & 83.3 & 56.7 & 76.7 & 0.32 & 0.08 & 0.20 \\
\hline HEERA & 96.7 & 60.0 & 56.7 & 0.38 & 0.41 & 0.40 \\
\hline KOSHIHIKARI & 83.3 & 43.3 & 76.7 & 0.48 & 0.08 & 0.28 \\
\hline SI-6 & 90.0 & 76.7 & 80.0 & 0.15 & 0.11 & 0.13 \\
\hline SI-7 & 80.0 & 50.0 & 76.7 & 0.38 & 0.04 & 0.21 \\
\hline IR-70 & 76.7 & 53.3 & 70.0 & 0.30 & 0.09 & 0.20 \\
\hline SKAU-403 & 83.3 & 56.7 & 50.0 & 0.32 & 0.40 & 0.36 \\
\hline
\end{tabular}


Table.3 Decrease in percentage of coleoptile length of thirty rice genotypes, obtained through comparison of their germination under normal temperature with germination under stressed conditions

\begin{tabular}{|c|c|c|c|c|c|}
\hline Genotypes & $\begin{array}{l}\text { Coleoptile } \\
\text { growth }(\%)(13 \\
\left.{ }^{\circ} \text { C for } 28 \text { days }\right)\end{array}$ & $\begin{array}{l}\text { Coleoptiles } \\
\text { growth }(\%)(17 \\
\left.{ }^{\circ} \text { C for } 28 \text { days }\right)\end{array}$ & Genotypes & $\begin{array}{l}\text { Coleoptile growth } \\
(\%)\left(13{ }^{\circ} \mathrm{C} \text { for } 28\right. \\
\text { days })\end{array}$ & $\begin{array}{l}\text { Coleoptiles growth } \\
(\%)\left(17^{\circ} \mathrm{C} \text { for } 28\right. \\
\text { days })\end{array}$ \\
\hline K332 & 82.8 & 89.7 & China-988 & 32.0 & 48.0 \\
\hline SKAU-407 & 42.9 & 57.1 & SKAU-411 & 76.9 & 80.8 \\
\hline IR-24 & 68.0 & 88.0 & Jehlum* & 62.1 & 79.3 \\
\hline IR-64 & 80.0 & 85.0 & SKAU-408 & 57.7 & 65.4 \\
\hline IR-72 & 45.5 & 72.7 & SI-5 & 76.5 & 94.1 \\
\hline SI-1 & 13.8 & 27.6 & Kamad & 74.1 & 85.2 \\
\hline Mushkbudji & 51.9 & 85.2 & China-1007 & 31.0 & 85.3 \\
\hline SKAU-5 (K-39) & 55.5 & 72.4 & Shalimar Rice-3 & 71.4 & 82.2 \\
\hline Shalimar Rice-2 & 52.6 & 68.4 & SI-3 & 68.0 & 92.0 \\
\hline SKAU-402 & 86.6 & 91.4 & HEERA & 62.1 & 58.6 \\
\hline Kohsaar & 64.3 & 82.2 & KOSHIHIKARI & 52.0 & 72.0 \\
\hline Shalimar Rice-1 & 44.4 & 63.0 & SI-6 & 85.2 & 88.9 \\
\hline SI-4 & 42.9 & 42.9 & SI-7 & 62.5 & 86.0 \\
\hline IR-52 & 15.4 & 38.5 & IR-70 & 56.6 & 64.4 \\
\hline SI-17 & 44.4 & 63.0 & SKAU-403 & 68.0 & 60.0 \\
\hline
\end{tabular}

Table.4 Radicle regrowth of 30 rice genotypes submitted to germination for 96 hours at $13^{\circ} \mathrm{C}$ and $72 \mathrm{~h}$ at $28^{\circ} \mathrm{C}$

\begin{tabular}{|c|c|c|c|c|c|c|c|}
\hline Genotypes & $\begin{array}{l}96 \mathrm{~h} \text { at } 13 \mathrm{c} \\
\text { (Length } 1)\end{array}$ & $\begin{array}{l}72 \mathrm{~h} \text { at } 28^{\circ} \mathrm{c} \\
\text { (Length 2) }\end{array}$ & $\begin{array}{l}\text { Radicle } \\
\text { Regrowth } \\
\text { (L2-L1) }\end{array}$ & Genotypes & $\begin{array}{l}96 \mathrm{~h} \text { at13 c } \\
\text { (Length 1) }\end{array}$ & $\begin{array}{l}72 \mathrm{~h} \text { at } 28^{0} \mathrm{c} \\
\text { (Length 2) }\end{array}$ & $\begin{array}{l}\text { Radicle } \\
\text { Regrowth } \\
\text { (L2-L1) }\end{array}$ \\
\hline K332 & 1.0 & 1.9 & 0.9 & China-988* & 0.5 & 0.8 & 0.3 \\
\hline SKAU-407** & 1.5 & 2.0 & 0.5 & SKAU-411** & 1.3 & 1.8 & 0.5 \\
\hline IR-24*** & 0.5 & 0.7 & 0.2 & Jehlum* & 1.6 & 1.9 & 0.3 \\
\hline IR-64*** & 0.7 & 1.2 & 0.5 & SKAU-408** & 2.1 & 2.9 & 0.8 \\
\hline IR-72**** & 1.0 & 1.3 & 0.3 & SI-5*** & 1.1 & 2.2 & 1.1 \\
\hline SI-1**** & 1.0 & 1.5 & 0.5 & Kamad* & 1.5 & 2.6 & 1.1 \\
\hline 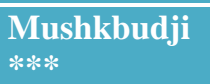 & 1.8 & 2.2 & 0.4 & China-1007* & 0.4 & 1.0 & 0.6 \\
\hline $\begin{array}{l}\text { SKAU-5 (K- } \\
39) *\end{array}$ & 2.1 & 2.9 & 0.8 & $\begin{array}{l}\text { Shalimar } \\
\text { Rice-3* }\end{array}$ & 0.9 & 1.7 & 0.8 \\
\hline $\begin{array}{l}\text { Shalimar } \\
\text { Rice-2* }\end{array}$ & 1.9 & 2.2 & 0.3 & SI-3*** & 1.7 & 2.6 & 0.9 \\
\hline SKAU-402*** & 0.6 & 1.6 & 1.0 & HEERA* & 1.0 & 1.5 & 0.5 \\
\hline Kohsaar*: & 1.8 & 2.2 & 0.4 & $\begin{array}{l}\text { KOSHIHIKA } \\
\text { RI* }\end{array}$ & 1.4 & 2.2 & 0.8 \\
\hline $\begin{array}{l}\text { Shalimar } \\
\text { Rice-1* }\end{array}$ & 1.7 & 2.2 & 0.5 & SI-6*** & 2.3 & 3.5 & 1.2 \\
\hline SI-4**** & 1.7 & 2.5 & 0.8 & SI-7*** & 2.0 & 2.4 & 0.4 \\
\hline IR-52**** & 0.5 & 0.7 & 0.2 & IR-70*** & 0.5 & 0.8 & 0.3 \\
\hline SI-17**** & 1.9 & 2.1 & 0.2 & $\begin{array}{l}\text { SKAU- } \\
403 * * *\end{array}$ & 1.2 & 1.7 & 0.5 \\
\hline
\end{tabular}


There was a significant difference in the radicle regrowth rate in the rice genotypes (Table 4). Radicle regrowth for all genotypes was varied from 2.0 to $12.0 \mathrm{~mm}$, and SI-6,-SI5, Kamad, SKAU-402 and K332, were the genotypes with high radicle regrowth. In the current study, radicle regrowth ability under cold stress in some of genotypes was remarkable. In this way, SI-6,-SI-5, Kamad, SKAU-402 and K332, genotypes had the highest and IR-24 and IR-72 had the lowest level of radicle regrowth. Measurement of radicle regrowth after a period of chilling stress is an important indicator of crop resistance to chilling stress (Rab and Saltveit, 1996a; 1996b). In general, there is a cold period between periods of high temperature in field conditions that leads to cold stress damage. Under these premises, and in order to simulate field conditions, experiment II was performed. Yoshida (1981a) demonstrated that the most influence of temperature on germination stage occurs in the phases of coleoptiles and radicle activation and growth. The reduction in coleoptile growth during these phases may be attributed to the direct effect of cold temperature on cellular elongation and division, or to its indirect effect leading to a metabolic unbalance (Lyons, 1973). The reduction in the length of the coleoptile under cold temperature of 18 ${ }^{\circ} \mathrm{C}$, helped in distinguishing the tolerant genotypes and sensitive ones (Farzin et al., 2013). Priyanka et al., (2015) evaluated cold tolerance of rice genotypes in terms of REDCOL. Cruz and Milach (2004) suggested that both REDCOL and COLREG seem to be the most adequate characteristics to be used to evaluate cold tolerance during the germination period in rice

\section{References}

Blum, A., 1988. Plant breeding for stress environments. Boca Raton: CRC Press. 99-132.
Cruz, R.P. and Milach, S.C.K., 2004. Cold tolerance at the germination stage of rice: Methods of evaluation and characterization of genotypes. Agri Sci, 61: $1-8$.

Cruz, R.P., Sperotto, R. A., Cargnelutti, D., Adamski, J. M., Terra, T. and Fett, J. P., 2013. Avoiding damage and achieving cold tolerance in rice plants. Food and Energy Security. 2(2): 96-119.

Datta, K., Datta, S.K., 2006. Indica rice (Oryza sativa, BR29 and IR64). Methods of Mol Biol, (343): 201-212.

Farzin, P.D., Mohammad, K.H. and Masoud, E., 2013. Methods for rice genotypes cold tolerance evaluation at germination stage. Int J. Agri and Crop Sci., 5-(18): 2111-2116.

Fukai, S. and Basnayake, J., 2002. Increased lowland rice production in the Mekong Region. Proceedings of an international workshop, Vientiane, Laos, 2000.Center for International Agricultural Research, Canberra, Australia.

INDIASTAT, 2013. http://www.indiastat. com/table/agriculture/2/rice/17194/5632 0/data.aspx.

Lee, M. H., 2001. Low temperature tolerance in rice: the Korean experience. Pp. 109117.

Lyons, J.M., 1973. Chilling injury in plants. Annual Review of Pl Physio, (24): 445466.

Miedema, P., 1982. The effects of low temperature on Zea mays. Advances in Agronomy, (35): 93-128.

Priyanka, K., Jaiswal, H.K., Waza, S. Aand Sravan, T., 2015. Response of rice seedlings to cold tolerance under boroconditions. Sabrao. J. Breed and Genet, 47(2): 185-190.

Rab A. and Saltveit, M.E., 1996b. Sensitivity of seedling radicles to chilling and heatshock induced chilling tolerance. J Am Soc Hortic Sci, 121: 711-715.

Rab, A. and Saltveit, M.E., 1996a. 
Differential chilling sensitivity in cucumber (Cucumis sativus) seedlings Plant Physiology, (96): 375-381.

Sharifi, P., 2010. Evaluation on sixty-eight rice germplasms in cold tolerance at germination. Rice Science. (17): 77-81.

Singh, R.P., Brennan, J.P., Farrell, T., Williams, R., Reinke, R. and Lewin, L., 2005. Economic analysis of breeding for improved cold tolerance in rice in Australia. Australian Agri Busi Rev, (1442)-6951.

Suh, J.P., Jeung, J.U., Lee, J.I., Choi, Y.H., Yea, J.D., Virk, P.S., Mackill, D.J, and Jena, K.K., 2010. Identification and analysis of QTLs controlling cold tolerance at the reproductive stage and validation of effective QTLs in cold tolerant genotypes of rice (Oryza sativa L.). Theo and Appl Genet, 120 (5): 985-995.

Xu, L. M., Zhou, L., Zeng, Y. W., Wang, F. M., Zhang, H. L., Shen, S.Q and Li, Z.C., 2008. Identification and mapping of quantitative trait loci for cold tolerance at the booting stage in a Japonica rice near isogenic line. Pl Sci. 174: 340-347.

Ye, C., Fukai, S., Godwin, I., Reinke, R., Snell, P., Schiller, J and Basnayake, J., 2009. Cold tolerance in rice varieties at different growth stages. Crop and Past Sci, 60: 328-338.

Yoshida, Y., 1981. Fundamentals of rice crop science. The International Rice Research Institute, 269.

\section{How to cite this article:}

Javeed A. Lone, M. Nisar Khan, M. Ashraf Bhat, Asif B. Shikari, Shabir H. Wani, Najeeb R. Sofi, M. Imran Khan and Rayees A. Lone. 2018. Cold Tolerance at Germination and Seedling Stages of Rice: Methods of Evaluation and Characterization of Thirty Rice Genotypes under Stress Conditions. Int.J.Curr.Microbiol.App.Sci. 7(01): 1103-1109. doi: https://doi.org/10.20546/ijcmas.2018.701.133 